\title{
Neglisjering av kronisk syke
}

\author{
Ventelistegarantien forverret situasjonen for kronikerne. Rutinesvikten som nå er avdekket ved Helse \\ Sør-Øst når det gjelder innkalling av pasienter til kontroll, kunne vært unngått dersom man hadde hatt \\ en garanti også for oppfølgingen.
}

En rapport om Helse Sør-Øst som kom nylig, fastslo at det er for lang ventetid og at det er manglende informasjon om tidsfrister, krav på behandling eller om hva som skal skje ved brudd på fristene ved fire av helseforetakets sykehus (1). Mange pasienter som er under behandling, får heller ikke innkalling til kontrolltime.

Undertegnede påpekte liknende problemer i et leserinnlegg i Aftenposten allerede for seks år siden (2). At pasienter ikke kalles inn til kontroll (1) er ikke nytt, men innføring av ventelistegarantien forverret situasjonen for kronikerne. Kontroller og oppfølging fikk ikke garanti. Løfte om kontroll som ikke innfris, er bare et løftebrudd, intet garantibrudd!

I det nevnte leserinnlegget foreslo jeg en «diagnoserelatert oppfølgingsgaranti», men statssekretær Elisabeth Aspaker svarte at det ikke var nødvendig, hun mente kontrollhyppigheten måtte avgjøres ut fra hva som var forsvarlig behandling (3). Mitt forslag om garanti var jo nettopp det! Nødvendig oppfølging bør nedfelles i poliklinikknotatet som sendes fastlegen, og avtalen må registreres ved poliklinikken. Tidsintervallene til neste fremmøte varierer ut fra behovet.

Jeg har ofte oppfordret mine pasienter om å minne sykehuset om kontrollen dersom de ikke har fătt den ønskede innkallingen. Direktør for Helse Sør-Øst Bente Mikkelsen påpeker da også i Aftenposten at «pasientene selv må følge med» (4). Min erfaring er at de fleste følger med, men at ikke alle purrer! For noen av de såkalt ressurssterke som i tillegg til å følge med også purrer og maser, kan dette fungere.

Vi har dessverre utallige eksempler fra alle aldersklasser, barn intet unntak, om at heller ikke purring hjelper. Kontroller er ikke innvilget garanti! Selv om en avtalt kontroll forsinkes med et helt år, er det tydeligvis ikke garantibrudd.

\section{«Det må ikke være sånn at de som roper høyest, får først»}

Jeg har vært i kontakt med en rekke pasienter som hadde ventet måneder og år på avtalt kontrolltime og som i forbindelse med en «opprydning i ventelistene» på Akershus universitetssykehus fikk brev om at hvis de fortsatt var interessert i oppfølging, kunne de ta telefonisk kontakt med en sykepleier for å avtale tid. Dette ble flere av mine pasienter meget indignert over.

Når en behandlende spesialist lover oppfølging av en pasient med en kronisk lidelse hvor forverring er regelen og stabilitet unntaket, må pasienten få en sikkerhet for kontroll til avtalt tid! Det er direkte demoraliserende for spesialister som behandler kronisk syke stadig å utsette pasientene sine for løftebrudd. Det må ikke være sånn at de som roper høyest, får først, men noe bedre råd har jeg ikke å gi dem nå. La oss få en mulighet til å bli til å stole på. Løftebrudd er ikke OK!

\section{Antonie Giæver Beiske}

agbeiske@gmail.com

MS-senteret i Hakadal

Antonie Giæver Beiske (f. 1949) er nevrolog og tidligere overlege ved nevrologisk avdeling Akershus universitetssykehus. Siden 1.9. 2011 har hun vært daglig leder ved MS-senteret i Hakadal.

Ingen oppgitte interessekonflikter.

\section{Litteratur}

1. Revisjon intern styring og kontroll av det pasientadministrative arbeidet i sykehuset Østfold HF. sykehuset Innlandet og Sørlandet sykehus HF. Rapport 4-6. Hamar: Konsernrevisjonen, Helse Sør-Øst, 2011.

2. Beiske AG. Ny pasient-«svarteliste». Aftenposten 14.7.2006 www.aftenposten.no/meninger/debatt/ article1080038.ece (22.9.2011)

3. Aspaker E. Nødvendig helsehjelp - for alle. Aftenposten 22.7.2006. www.aftenposten.no/meninger/ debatt/article1084309.ece (22.9.2011).

4. Dommerud T. Pasientene må selv følge med. Aftenposten 8.9.2011 www.nyhetspressen.com/ 164943.html (23.10.2011).

Mottatt 20.9. 2011 og godkjent 27.10. 2011.

Medisinsk redaktør Anne Kveim Lie. 